\title{
Epoxy Functionalized Carboxymethyl Dextran Magnetic Nanoparticles for Immobilization of Alcohol Dehydrogenase
}

\author{
Katja Vasić, ${ }^{1}$ Željko Knez, ${ }^{1,2}$ Sanjay Kumar, ${ }^{3}$ Jitendra K. Pandey ${ }^{4}$ \\ and Maja Leitgeb ${ }^{1,2^{*}}$ \\ ${ }^{1}$ University of Maribor, Faculty of Chemistry and Chemical Engineering, Smetanova 17, SI-2000 Maribor, \\ Slovenia, phone: +38622294 462, e-mail: maja.leitgeb@um.si \\ ${ }^{2}$ University of Maribor, Faculty of Medicine, Taborska ulica 8, SI-2000 Maribor, Slovenia \\ ${ }^{3}$ University of Petroleum and Energy Studies, Department of Chemistry, Dehradun, Uttarakhand, India \\ ${ }^{4}$ University of Petroleum and Energy Studies, Research and Developments, Dehradun, Uttarakhand, India \\ *Corresponding author: E-mail: maja.leitgeb@um.si
}

Received: 04-25-2020

\begin{abstract}
Microbial inhibition of carboxymethyl dextran (CMD) magnetic nanoparticles (MNPs) was investigated on two different bacterial cultures, Escherichia coli and Staphylococcus aureus, where inhibition properties of CMD-MNPs were confirmed, while uncoated MNPs exhibited no inhibition properties. To such CMD-MNPs, enzyme alcohol dehydrogenase (ADH) from Saccharomyces cerevisiae was immobilized. Later on, CMD-MNPs were functionalized, using an epoxide cross-linker epiclorohydrin (EClH) for another option of ADH immobilization. Residual activities of immobilized ADH onto epoxy functionalized and non-functionalized CMD-MNPs were determined. Effect of cross-linker concentration, temperature of immobilization and enzyme concentration on residual activities of immobilized ADH were determined, as well. With optimal process conditions $\left(4 \%(\mathrm{v} / \mathrm{v}) \mathrm{EClH}, 4{ }^{\circ} \mathrm{C}\right.$ and $0.02 \mathrm{mg} / \mathrm{mL}$ of ADH), residual activity of immobilized ADH was 90\%. Such immobilized ADH was characterized using FT-IR, SEM and DLS analysis.
\end{abstract}

Keywords: Alcohol dehydrogenase, carboxymethyl dextran, epoxy functionalization, epichlorohydrin, enzyme activity

\section{Introduction}

As versatile and efficient enzyme, alcohol dehydrogenases (ADH) has always had an important role in modern green chemistry, especially since it can perform selective oxidations and reductions. ${ }^{1,2}$ ADHs have many applications in production of various intermediates in chemical industries, such as production of chiral compounds, regeneration of different cofactors and in biosensors. ${ }^{3-6}$ However, poor stability presents a limitation in the industrial use of $\mathrm{ADH}$ and many strategies have been developed to improve and increase its stability. These methods include protein engineering, chemical modification and most commonly used immobilization. ${ }^{7-11}$

Iron oxide nanoparticles are often used as nanocarriers for enzyme immobilization and present a promising tool in various medical fields, which has numerous clinical applications, such as targeted drug delivery, cell labelling, tissue repairment and various applications in biosensors. ${ }^{12-16}$ Magnetic nanoparticles (MNPs) have unique properties, such as superparamagnetism, large surface area and low toxicity. ${ }^{17-19}$ However, they are inclined to aggregate, because of their strong magnetic dipole. ${ }^{20,21}$ To avoid such aggregation, modification of nanoparticles is in place. In our study, we used organic polymer carboxymethyl dextran (CMD) to provide better biocompatibility and biodegradability with low toxicity of synthesized MNPs. ${ }^{22-25}$

Modified MNPs are usually further functionalized using different functionalization groups. Epoxy functional group is a very active group, which can react with proteins, enzymes and nucleic acids, resulting in beneficial immobilization of biomolecules. Epoxy groups are also very stable 
at neutral $\mathrm{pH}$ values, therefore different commercial supports can be prepared at a far position, where the enzyme has to be immobilized, which means epoxy-activated supports are very suitable biological systems to develop easy enzyme immobilization protocols. ${ }^{26,27} \mathrm{EClH}$ is an epoxide with bifunctional alkylating activity and is routinely used in the production of numerous synthetic materials, including epoxy, phenoxy and polyamide resins, cross-linked starch, surfactants and many pharmaceutical products. ${ }^{28}$ There are studies describing epoxy-functionalized nanoparticles, modified with silica, as a carrier for immobilization of $\mathrm{ADH}$ from horse liver to be a suitable support for immobilization of $\mathrm{ADH},{ }^{29,30}$ and studies reporting of immobilization of lipase and laccase covalently immobilized on magnetic microspheres, silica nanoparticles or chitosan magnetic beads via active epoxy groups. ${ }^{31-33}$ All reported studies show the importance and significance of epoxy-functionalized nanoparticles, suitable for enzyme immobilization.

As there are many research studies investigating immobilization of $\mathrm{ADH}$ onto different magnetic supports, there are none that report about immobilization of $\mathrm{ADH}$ onto functionalized CMD-MNPs, using epichlorohydrin as an epoxide cross-linker. In our study, effect of process parameters was investigated, such as cross-linker concentration, temperature of immobilization and enzyme concentration to obtain the highest residual activity of immobilized ADH. Additionally, characterization of such immobilized ADH was performed using FT-IR, SEM and DLS analysis.

\section{Materials and Methods}

\section{1. Materials}

CMD sodium salt, sodium phosphate, sodium pyrophosphate, EClH (1-Chloro-2,3-epoxypropane), ethanol, $\beta$-nicotinamide adenine dinucleotide ( $\beta$-NAD) and $\mathrm{ADH}$ from $S$. cerevisiae were purchased from Sigma-Aldrich. Iron (III) chloride hexahydrate $\left(\mathrm{FeCl}_{3} \cdot 6 \mathrm{H}_{2} \mathrm{O}\right)$, iron (II) chloride tetrahydrate $\left(\mathrm{FeCl}_{2} \cdot 4 \mathrm{H}_{2} \mathrm{O}\right)$, Coomassie brilliant blue, Peptone from meat, Meat extract, agar, Yeast extract and Tryptic soy broth were obtained from Merck. Ammonium hydroxide was purchased from Chem-Lab, Belgium. All reagents in this work were of analytical purity and used without further purification. In all experiments, deionized water was used.

\section{2. Methods}

\section{2. 1. Synthesis and Toxicity of CMD-MNPs}

CMD-MNPs were prepared by protocol developed in our previous research, published by Vasić et al. ${ }^{34}$ Further we wanted to investigate the toxicity of the prepared CMD-MNPs. This was tested on two different bacterial cultures, Gram negative E. coli and Gram positive S. au-
Table 1. Growth media for E. coli and S. aureus

\begin{tabular}{lrlr}
\hline E. coli & \multicolumn{3}{c}{ S. aureus } \\
\hline Peptone from meat & $5 \mathrm{~g}$ & Tryptic Soy Broth & $30 \mathrm{~g}$ \\
Meat extract & $3 \mathrm{~g}$ & Yeast extract & $3 \mathrm{~g}$ \\
Agar & $15 \mathrm{~g}$ & Agar & $15 \mathrm{~g}$ \\
Distilled $\mathrm{H} 2 \mathrm{O}$ & $1 \mathrm{~L}$ & Distilled $\mathrm{H}_{2} \mathrm{O}$ & $1 \mathrm{~L}$ \\
\hline
\end{tabular}

reus. Growth media for both bacterial cultures was prepared according to Table 1, later on sterilized and prepared as growth medium in a petri dish. E. coli and S. aureus with concentration of $10^{5} \mathrm{CFU} / \mathrm{mL}$ were smeared on a petri dish, to which 10-30 mg of CMD-MNPs was added. Petri dishes with culture E. coli and $S$. aureus, together with CMD-MNPs, were incubated at $37^{\circ} \mathrm{C}$ for 24 hours.

\section{2. 2. Immobilization of ADH Onto CMD-MNPs}

To CMD-MNPs, ADH and sodium acetate buffer $(10 \mathrm{mM})$ were added with a volumetric ratio 1:9. Final $\mathrm{ADH}$ concentration in the reaction mixture was $0.02 \mathrm{mg} /$ $\mathrm{mL}$. Immobilization was carried out for 2 hours at $4{ }^{\circ} \mathrm{C}$ and $22{ }^{\circ} \mathrm{C}$, with $500 \mathrm{rpm}$.

\section{2. 3. Epoxy Functionalization of CMD-MNPs}

CMD-MNPs were functionalized with $4 \%(\mathrm{v} / \mathrm{v})$ $\mathrm{EClH}(0.5 \mathrm{M})$ in $10 \mathrm{mM}$ sodium acetate buffer, $\mathrm{pH}$ 7.5. Functionalization was carried out with continuous mixing for 1 hour at $300 \mathrm{rpm}$ and $22^{\circ} \mathrm{C}$. After functionalization, the supernatant was removed and epoxy functionalized CMD-MNPs were obtained.

\section{2. 4. Immobilization of ADH Onto Epoxy Functionalized CMD-MNPs}

To epoxy functionalized CMD-MNPs, ADH and sodium acetate buffer $(10 \mathrm{mM})$ were added with a volumetric ratio 1:9. Final $\mathrm{ADH}$ concentration in the reaction mixture was $0.02 \mathrm{mg} / \mathrm{mL}$. Immobilization was carried out for 2 hours at $4{ }^{\circ} \mathrm{C}$ and $22^{\circ} \mathrm{C}$, with $500 \mathrm{rpm}$.

\section{2. 5. Assay for ADH Activity}

The activity of soluble and immobilized ADH was determined spectrophotometrically using ethanol as a substrate. The standard reaction mixture in a total volume of $3 \mathrm{~mL}$ contained $22 \mathrm{mM}$ sodium pyrophosphate, $3.2 \%$ $(\mathrm{v} / \mathrm{v})$ ethanol, $7.5 \mathrm{mM} \beta-\mathrm{NAD}, 0.3 \mathrm{mM}$ sodium phosphate and $0.003(\mathrm{w} / \mathrm{v}) \%$ BSA. The reaction was initiated by the addition of ethanol and $\beta$-NAD to soluble or immobilized $\mathrm{ADH}$, and subsequently the increase in absorbance at 340 $\mathrm{nm}$ due to formation of $\beta-\mathrm{NADH}$ was measured.

The activity of soluble and immobilized $\mathrm{ADH}$ was calculated using the following equation: 
$\frac{\text { Units }}{m L}$ enzyme $=$

$=\frac{\left(\left(\Delta \mathrm{A}_{340 \mathrm{~nm}} / \mathrm{min}\right) \text { of SAMPLE }-\left(\Delta A_{340 \mathrm{~nm}} / \mathrm{min}\right) \text { of } B L A N K\right) * 3 * d f}{6.22 * 0.1}$

where:

$$
\begin{aligned}
3 & \text { - total volume }(\mathrm{mL}) \text { of assay } \\
\mathrm{df} & \text { - dilution factor } \\
6.22 & \text { - millimolar extinction coefficient of } \beta \text {-NADH } \\
& \text { at } 340 \mathrm{~nm} \\
0.1 & \text { - volume }(\mathrm{mL}) \text { of enzyme used }
\end{aligned}
$$

Enzymatic activity of $\mathrm{ADH}$ was measured in triplicates by enzymatic assay for ADH by Sigma-Aldrich protocol, ${ }^{35}$ and the residual activity was calculated from the following equation:

$$
\text { Residual activity }(\%)=\frac{\text { activity of immobilized ADH }}{\text { activity of soluble ADH }} * 100
$$

\section{2. 6. Protein amount determination and immobilization efficiency calculation}

The protein amount of non-immobilized and immobilized $\mathrm{ADH}$ was determined by measuring the protein concentration by Bradford method using Bovine serum albumin (BSA) as a standard. ${ }^{36}$ The amount of ADH immobilized on the surface of CMD-MNPs was determined on the basis of the protein amount in supernatant fraction $\left(\mathrm{c}_{\mathrm{s}}\right)$ and later calculated by subtracting the measured amount $\left(c_{s}\right)$ from the amount of non-immobilized $\operatorname{ADH}\left(c_{\mathrm{e}}\right)$.

Immobilization efficiency was calculated using the following equation:

$$
\text { Immobilization efficiency }(\%)=\frac{c_{e}-c_{S}}{c_{e}} * 100
$$

where:

$c_{\mathrm{s}}$ - protein concentration in supernatant fraction of immobilized $\mathrm{ADH}$

$c_{\mathrm{e}}$ - protein concentration of non-immobilized $\mathrm{ADH}$

All measurements for activity and protein amount determination were performed in triplicates and exhibited a standard deviation of less than $2 \%$.

\section{3. Characterization}

\subsection{FT-IR}

FT-IR spectra were recorded to study chemical bonds formed between ADH immobilized CMD-MNPs. FT-IR analysis of the samples was performed by pressing the samples to form a tablet using $\mathrm{KBr}$ as the matrix. The spectra were detected over a range of $4000-500 \mathrm{~cm}^{-1}$ and recorded by a FT-IR spectrophotometer (Perkin Elmer 1600 Fourier transform infrared spectroscopy spectrophotometer).

\section{3. 2. SEM}

The morphology and size of CMD-MNPs and ADHCMD-MNPs was investigated by SEM analysis using a scanning electron microscope (FE, SEM SIRION, 400 NC, $\mathrm{FEI})$. The samples were measured on a gold $(\mathrm{Au})$ substrate.

\subsection{DLS}

The particle size distribution, hydrodynamic size and $\zeta$-potentials of the samples were measured using DLS (Zetasizer Nano ZS). Each diameter value was the average of three consecutive measurements. Higher values indicate a very broad size distribution, whereas lower values correspond to more or less monodisperse particle size distributions. Measurements were carried out under equilibrium conditions. Measured samples were dispersed in water with neutral $\mathrm{pH}$ at room temperature. Concentration of all CMD-MNPs and ADH-CMD-MNPs were $2 \mathrm{mg} / \mathrm{mL}$.

\section{Results and Discussion}

\section{1. Toxicity of CMD-MNPs}

Inhibition properties of synthesized CMD-MNPs on the growth of bacterial cultures $E$. coli and $S$. aureus were investigated, compared to uncoated magnetic nanoparticles. Qualitative assessment of inhibition properties was determined after incubation for 24 hours at $37{ }^{\circ} \mathrm{C}$. If the
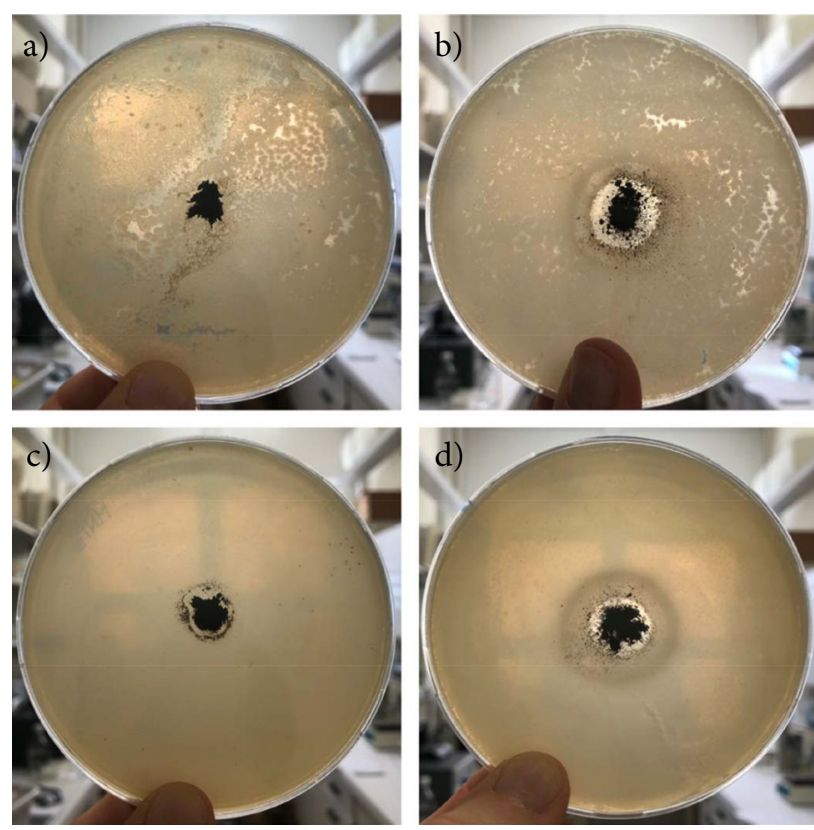

Figure 1. Uncoated MNPs on bacterial culture E. coli after incubation at $37^{\circ} \mathrm{C}$ for 24 hours (a), CMD-MNPs on bacterial culture $E$. coli after incubation at $37^{\circ} \mathrm{C}$ for 24 hours, where inhibition zone can be seen (b), uncoated MNPs on bacterial culture S. aureus after incubation at $37{ }^{\circ} \mathrm{C}$ for 24 hours (c) and CMD-MNPs on bacterial culture $S$. aureus after incubation at $37^{\circ} \mathrm{C}$ for 24 hours, where inhibition zone can be seen (d). 
inhibition zone was present, additional quantitative assessment was performed. Figure 1 shows that inhibition occurs when CMD-MNPs were incubated with both bacterial cultures, while uncoated MNPs exhibited no inhibition properties. Additional quantitative assessment revealed that the average inhibition zone was $19.7 \mathrm{~mm}$ when incubated with $E$. coli and $19 \mathrm{~mm}$, when incubated with $S$. aureus. CMD-MNPs exhibit antibacterial properties, since they are modified with organic polymer CMD. The modification of MNPs with organic polymers makes MNPs biocompatible, biodegradable and mostly non-toxic, which is a favourable advantage with using suitable support for immobilization of enzymes. ${ }^{17,18,37}$

\section{2. ADH Immobilization}

ADH was immobilized onto CMD-MNPs, which were not epoxy functionalized and onto epoxy functionallized CMD-MNPs at two different immobilization temperatures, $4{ }^{\circ} \mathrm{C}$ and $22^{\circ} \mathrm{C}$. As seen from Figure 2a, residual activities increased drastically, when $\mathrm{ADH}$ was immobilized onto epoxy functionalized CMD-MNPs. Residual activity at $22{ }^{\circ} \mathrm{C}$ increased from $15 \%$ to $39 \%$, while at $4{ }^{\circ} \mathrm{C}$ it increased even more, from $26 \%$ to $87 \%$. Results suggest that epoxy functionalized CMD-MNPs ensure more successful immobilization of ADH onto the surface of the carrier, since the functionalization of CMD-MNPs provides additional epoxy functional groups, to which the amino groups of the enzyme can bind.

Further, we the influence of cross-linker concentration on the residual ADH activity was studied. The concentration of $\mathrm{EClH}$ was optimized by performing immobilization of $\mathrm{ADH}$ onto $\mathrm{CMD}-\mathrm{MNPs}$ with different volumetric ratios of $0.5 \mathrm{M} \mathrm{EClH}$ as a cross-linking reagent. Enzyme residual activity was determined with the help of enzymatic assay for $\mathrm{ADH}$ determination, using ethanol as
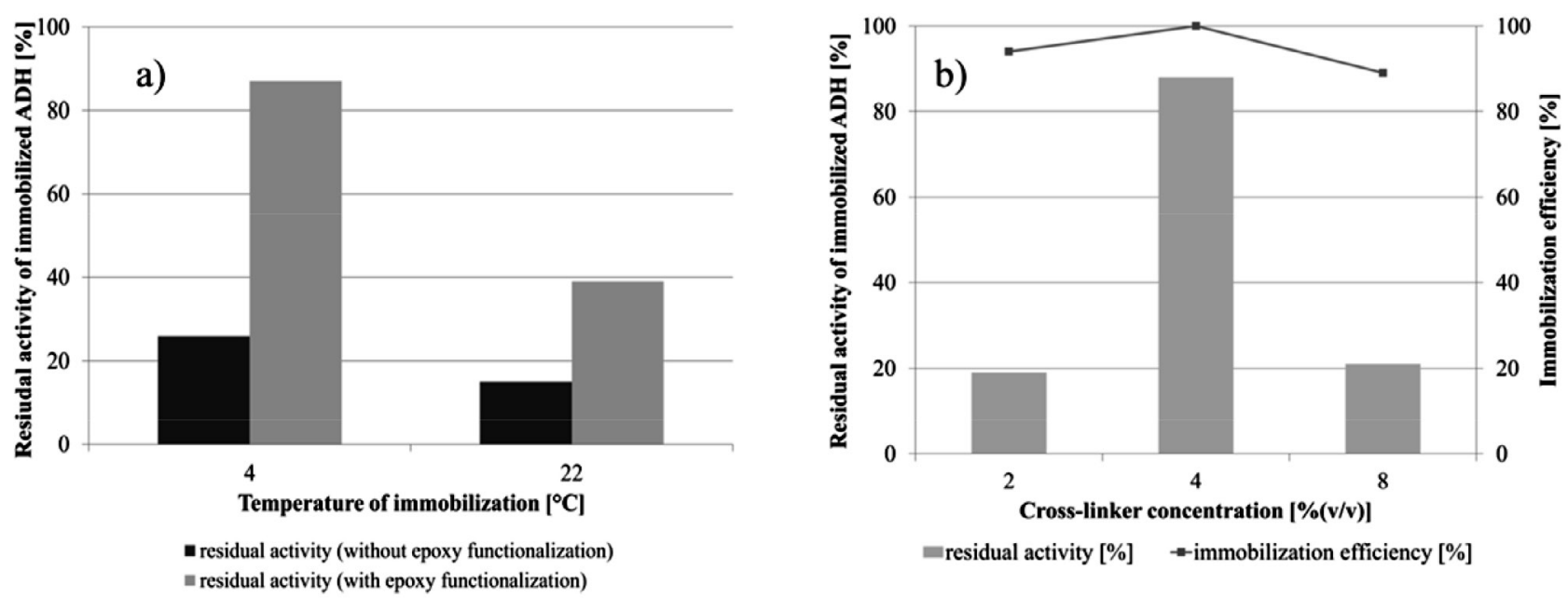

Figure 2. Residual activities of $\mathrm{ADH}$ immobilized onto CMD-MNPs, while investigating temperature of immobilization with and without epoxy functionalization (a) and cross-linker concentration (b).

Vasić et al.: Epoxy functionalized carboxymethyl ...

a substrate and immobilization efficiency was determined with the help of estimating the protein concentration with Bradford method in supernatants after immobilization and 2 times washing of the immobilized ADH-CMDMNPs. As shown in Figure 2b, when applying 2\% (v/v) of $\mathrm{EClH}$, the residual activity was very low, only $19 \%$, which could suggest that low cross-linker concentration gives poor mechanism strength, easily leading to leaching of the enzyme from carrier support. By doubling the concentration of cross-linker $\mathrm{EClH}$ to $4 \%(\mathrm{v} / \mathrm{v})$, the residual activity started to increase and was found to be optimal volumetric concentration, since it retained $88 \%$ of the original enzyme activity. With increasing cross-linker concentration, the amount of free active groups on the surface of the carrier resulted in higher $\mathrm{ADH}$ loading, causing higher residual activity of immobilized $\mathrm{ADH}$. Also, immobilization efficiency was very high, resulting in $100 \%$. In this case, immobilization efficiency goes hand-in-hand with the residual activity of $\mathrm{ADH}$. With doubling the concentration of cross-linker $\mathrm{EClH}$ again, to $8 \%(\mathrm{v} / \mathrm{v})$, residual activity and enzyme immobilization efficiency started to decrease. The significant residual activity decrease to $21 \%$ at $8 \%$ $(\mathrm{v} / \mathrm{v})$ of $\mathrm{EClH}$ suggests that the limit of cross-linking was reached. Too high concentration of cross-linker can result in enzyme deactivation on one hand and on the other hand the loss of activity happens because access concen-

Table 1. Residual activities and immobilization efficiency of ADH immobilized onto epoxy functionalized CMD-MNPs, while investigating time of immobilization.

\begin{tabular}{ccc}
\hline $\begin{array}{c}\text { Time of } \\
\text { immobilization [h] }\end{array}$ & $\begin{array}{c}\text { Residual } \\
\text { activity [\%] }\end{array}$ & $\begin{array}{c}\text { Immobilization } \\
\text { efficiency [\%] }\end{array}$ \\
\hline 2 & 87 & 100 \\
12 & 37 & 96 \\
\hline
\end{tabular}


trations of cross-linker result in blocking of enzyme active groups. ${ }^{38}$ Immobilization efficiency was $89 \%$ for $8 \%(\mathrm{v} / \mathrm{v})$ and $94 \%$ for $2 \%(\mathrm{v} / \mathrm{v})$ of used $\mathrm{EClH}$.

The influence of immobilization time is presented in Table 1. At first, immobilization time was investigated at 2 hours, and later on prolonged to 12 hours. When performing immobilization for 2 hours, residual activity of immobilized ADH-CMD-MNPs of $87 \%$ with $100 \%$ immobilization efficiency was achieved. When the immobilization time was prolonged to 12 hours, the residual activity of immobilized ADH-CMD-MNPs decreased drastically, to $37 \%$ with $96 \%$ immobilization efficiency. The results indicate that the immobilization time has an important effect on residual activity of immobilized ADH-CMD-MNPs and that the optimal immobilization lasts for 2 hours, which is sufficient time to bind enzyme ADH effectively to CMD-MNPS surface with its highest possible activity.

Table 2. Residual activities and immobilization efficiency of ADH immobilized onto epoxy functionalized CMD-MNPs, while investigating enzyme concentration.

\begin{tabular}{ccc}
\hline $\begin{array}{c}\text { Enzyme concentration } \\
{[\mathbf{m g} / \mathbf{m L}]}\end{array}$ & $\begin{array}{c}\text { Residual } \\
\text { activity [\%] }\end{array}$ & $\begin{array}{c}\text { Immobilization } \\
\text { efficiency [\%] }\end{array}$ \\
\hline 0.02 & 87 & 100 \\
0.04 & 42 & 31 \\
\hline
\end{tabular}

An increase in $\mathrm{ADH}$ concentration is suggested to yield in a more active product. However, with increase of enzyme concentration to $0.04 \mathrm{mg} / \mathrm{mL}$ the residual activity of immobilized ADH-CMD-MNPs decreased. When the $\mathrm{ADH}$ concentration was increased from $0.02 \mathrm{mg} / \mathrm{mL}$ to $0.04 \mathrm{mg} / \mathrm{mL}$ the residual activity decreased to $42 \%$ and immobilization efficiency decreased slightly more, to $31 \%$. Results can be observed in Table 2. The decrease in residual activity with increasing enzyme concentration can be attributed to the oversaturation of the enzyme over the support surface. As enzyme has an active site, it is available for substrate binding to form a product. When enzyme molecules crowd on the support surface, due to high enzyme concentration, enzyme molecules tend to overlap each other. That overlapping leads to inaccessibility of enzyme molecules' active sites, therefore can not be bind with the substrate. As a consequence of this inaccessibility, the product can not be formed, which is expressed as reduced enzyme activity or denaturation of immobilized enzyme. ${ }^{39-42}$

\section{3. Characterization}

\section{3. 1. FTIR, SEM, DLS}

Present peaks from FT-IR spectra of CMD-MNPs, $\mathrm{ADH}-\mathrm{CMD}-\mathrm{MNPs}$ and free ADH are presented in Table 3. $\mathrm{ADH}$ enzyme complex in ADH-CMD-MNPs shows characteristic absorption peaks at $1330 \mathrm{~cm}^{-1}, 1640 \mathrm{~cm}^{-1}$ and $1450 \mathrm{~cm}^{-1}$ which can also be observed in the free ADH spectra, exhibiting characteristic frequencies of ADH complex at $1640 \mathrm{~cm}^{-1}$ and $1390 \mathrm{~cm}^{-1}$. The symmetric ring stretching frequency of the epoxy ring around 813, 921, and $1269 \mathrm{~cm}^{-1}$ were presented, indicating the existence of epoxy group on epoxy functionalized CMD-MNPs. The absorption peaks at $569 \mathrm{~cm}^{-1}$ and $682 \mathrm{~cm}^{-1}$ belong to the stretching vibration modes of $\mathrm{Fe}-\mathrm{O}$ bond of synthesized MNPs. Characteristic adsorption peaks are shown at $1010 \mathrm{~cm}^{-1}$, which corresponds to $\mathrm{CMD} v \mathrm{C}-\mathrm{O}$ vibrations, while the broad absorption peak at $3408 \mathrm{~cm}^{-1}$ corresponds to the characteristic $v \mathrm{O}-\mathrm{H}$ stretching and $\delta \mathrm{O}-\mathrm{H}$ deformation modes of CMD hydroxyl groups, also CMD carboxyl groups are represented in absorption peak at $1642 \mathrm{~cm}^{-1}$. FTIR spectra is available in Supplementary Material 1.

The morphology of epoxy functionalized CMDMNPs with immobilized ADH was investigated by SEM. Figure 3 shows SEM images of CMD-MNPs and epoxy functionalized $\mathrm{ADH}-\mathrm{CMD}-\mathrm{MNPs}$. It is evident that CMD-MNPs and ADH-CMD-MNPs are spherical in shape and monodispersed. However, before immobilization of ADH, CMD-MNPs had more uniform size, which was in average $28 \mathrm{~nm}$, as can be observed in our previous

Table 3. Peaks from FT-IR spectra, present in soluble ADH, CMD-MNPs and ADH-CMD-MNPs.

\begin{tabular}{ccccc}
\hline $\begin{array}{c}\text { Wavenumber } \\
{\left[\mathbf{c m}^{-1}\right]}\end{array}$ & $\begin{array}{c}\text { Functional } \\
\text { group }\end{array}$ & $\begin{array}{c}\text { Soluble } \\
\text { ADH }\end{array}$ & CMD-MNPs & ADH-CMD-MNPs \\
\hline 569 & Fe-O & & $\mathrm{x}$ & $\mathrm{x}$ \\
682 & Fe-O & & $\mathrm{x}$ & $\mathrm{x}$ \\
813 & epoxy & & $\mathrm{x}$ & $\mathrm{x}$ \\
921 & epoxy & & $\mathrm{x}$ & $\mathrm{x}$ \\
1010 & vC-O & & $\mathrm{x}$ & $\mathrm{x}$ \\
1269 & epoxy & $\mathrm{x}$ & & $\mathrm{x}$ \\
1330 & ADH complex & $\mathrm{x}$ & & $\mathrm{x}$ \\
1390 & ADH complex & $\mathrm{x}$ & & $\mathrm{x}$ \\
1450 & ADH complex & $\mathrm{x}$ & $\mathrm{x}$ & $\mathrm{x}$ \\
1640 & ADH complex & & & $\mathrm{x}$ \\
3408 & vO-H, $\delta \mathrm{O}-\mathrm{H}$ & & $\mathrm{x}$ \\
\hline
\end{tabular}

Vasić et al.: Epoxy functionalized carboxymethyl ... 

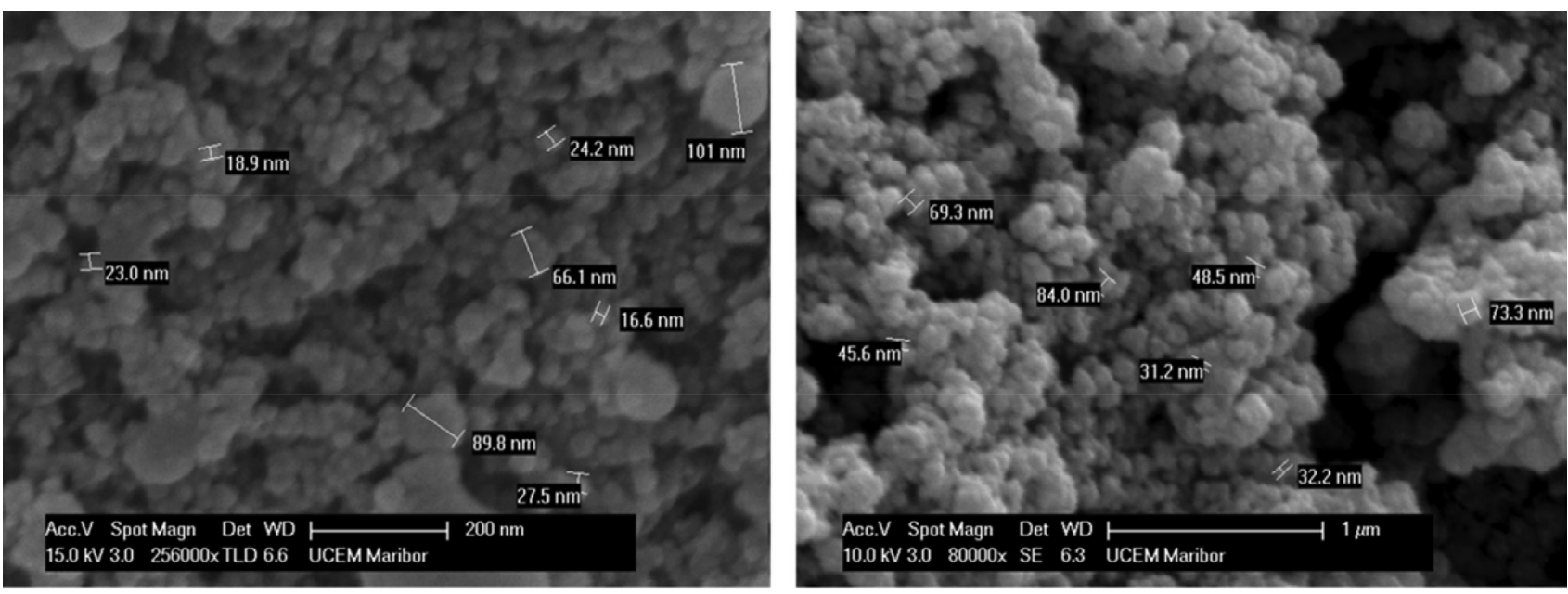

Figure 3. SEM images of CMD-MNPs (left) and ADH-CMD-MNPs (right).

research. ${ }^{34}$ After immobilization CMD-MNPs are covered with a layer of enzyme due to epoxy functionalization, which allows ADH to covalently bind to CMD-MNPs. The sizes are slightly uneven and increased in diameter, ranging from $57 \mathrm{~nm}$ to $84 \mathrm{~nm}$. Therefore, SEM images give additional evidence that ADH has been successfully bound to the surface of CMD-MNPs by covalent attachment resulting in the nano-sized product.

Zeta potential of CMD-MNPs and ADH-CMDMNPs was measured to indicate the stability of colloidal dispersion. Both prepared CMD-MNPs and immobilized ADH-CMD-MNPs exhibit negative zeta potentials, -31.9 $\mathrm{mV}$ and $-26.8 \mathrm{mV}$, respectively, which indicate negatively charged hydroxyl and carboxyl groups of CMD present on the surface of nanoparticles. Zeta potentials indicate that CMD-MNPs and ADH-CMD-MNPs show good dispersion in the aqueous phase. The size distribution of nanoparticles is expressed in polydispersity index (PdI). The PdI of ADH-CMD-MNPs is slightly higher, which is due to the layer of $\mathrm{ADH}$, immobilized on the surface of CMD-MNPs, which can also be observed from SEM images. Because ADH-CMD-MNPs are slightly uniform in size, the PdI index increases, as well. PdI values are presented in Table 4.

Table 4. Zeta-potential and PdI obtained by DLS analysis of CMDMNPs and ADH-CMD-MNPs. Sample

\begin{tabular}{ccc}
\hline Sample & Zeta-potential (mV) & PdI \\
CMD-MNPs & -31.9 & 0.31 \\
ADH-CMD-MNPs & -26.8 & 0.53 \\
\hline
\end{tabular}

\section{Conclusions}

To conclude, CMD-MNPs were successfully functionalized with cross-linking of epoxide $\mathrm{EClH}$ for covalent attachment of ADH. Cross-linker concentration, tempera- ture of immobilization and enzyme concentration were successfully optimized, resulting in $90 \%$ of residual activity of immobilized $\mathrm{ADH}$. Characterization of immobilized $\mathrm{ADH}$ onto functionalized CMD-MNPs revealed successful covalent attachment and confirmed immobilization of $\mathrm{ADH}$. The resulting CMD-MNPs with immobilized ADH were spherical in shape and measured from $57 \mathrm{~nm}$ to $84 \mathrm{~nm}$ in diameter. The results indicated that epoxy functionalized CMD-MNPs are favourable for ADH immobilization.

\section{Acknowledgment}

The authors acknowledge the financial support from the Slovenian Research Agency, research core funding Nr. P2-0046 - "Separation Processes and Product Design" and research core funding Nr. J2-1725 - "Smart materials for bioapplications", "and grant INT/Slovenia/P-16/2014".

\section{References}

1. de Smidt, O.; du Preez, J. C.; Albertyn, J. FEMS Yeast Res 2008, 8, 967-978. DOI:10.1111/j.1567-1364.2008.00387.x

2. Raj, S. B.; Ramaswamy, S.; Plapp, B. V. Biochemistry 2014, 53, 5791-5803. DOI:10.1021/bi5006442

3. Hummel, W.; Kula, M.-R. European Journal of Biochemistry 1989, 184, 1-13. DOI:10.1111/j.1432-1033.1989.tb14983.x

4. Alpat, S.; Telefoncu, A. Sensors (Basel) 2010, 10, 748-764. DOI: $10.3390 / \mathrm{s} 100100748$

5. Patel, R. N. Coordination Chemistry Reviews 2008, 252, 659701. DOI:10.1016/j.ccr.2007.10.031

6. Demirkòran, N.; Ekinci, E. Acta Chim Slov 2012, 59, 302-306.

7. Bernal, C.; Rodríguez, K.; Martínez, R. Biotechnology Advances 2018, 36, 1470-1480.

DOI:10.1016/j.biotechadv.2018.06.002

8. Cowan, D. A.; Fernandez-Lafuente, R. Enzyme and Microbial Technology 2011, 49, 326-346.

DOI:10.1016/j.enzmictec.2011.06.023 
9. Ahmad, R.; Sardar, M. Biochemistry \& Analytical Biochemistry 2015, 0, 1-8. DOI:10.4172/2161-1009.1000178

10. Stojkovič, G.; Znidaršič-Plazl, P. Acta Chim Slov 2010, 57, 144-149.

11. Primožič, M.; Podrepšek, G.H.; Pavlovič, I.; Škerget, M.; Knez, Ž.; Leitgeb, M. Acta Chimica Slovenica 2019, 66, 732739. DOI:10.17344/acsi.2019.5013

12. Hola, K.; Markova, Z.; Zoppellaro, G.; Tucek, J.; Zboril, R. Biotechnology Advances 2015, 33, 1162-1176.

DOI:10.1016/j.biotechadv.2015.02.003

13. Tarvirdipour, S.; Vasheghani-Farahani, E.; Soleimani, M.; Bardania, H. International Journal of Pharmaceutics 2016, 501, 331-341. DOI:10.1016/j.ijpharm.2016.02.012

14. Agiotis, L.; Theodorakos, I.; Samothrakitis, S.; Papazoglou, S.; Zergioti, I.; Raptis, Y.S. Journal of Magnetism and Magnetic Materials 2016, 401, 956-964.

DOI:10.1016/j.jmmm.2015.10.111

15. Masood, F. Materials Science and Engineering: C 2016, 60, 569-578. DOI:10.1016/j.msec.2015.11.067

16. Kravanja, G.; Primožič, M.; Knez, Ž.; Leitgeb, M. Molecules 2019, 24, 1-23. DOI:10.3390/molecules 24101960

17. Leitgeb, M.; Heržič, K.; Podrepšek, G.H.; Hojski, A.; Crnjac, A.; Knez, Z. Toxicity of magnetic chitosan micro and nanoparticles as carriers for biologically active substances. Acta Chim Slov 2014, 61, 145-152.

18. Liu, G.; Gao, J.; Ai, H.; Chen, X. Small 2013, 9, 1533-1545. DOI:10.1002/smll.201201531

19. Markides, H.; Rotherham, M.; El Haj, A.J. Journal of Nanomaterials 2012, 2012, 1-11. DOI:10.1155/2012/614094

20. Hauser, A.K.; Mathias, R.; Anderson, K.W.; Zach Hilt, J. Materials Chemistry and Physics 2015, 160, 177-186.

DOI:10.1016/j.matchemphys.2015.04.022

21. Wei, Y.; Han, B.; Hu, X.; Lin, Y.; Wang, X.; Deng, X. Procedia Engineering 2012, 27, 632-637.

DOI:10.1016/j.proeng.2011.12.498

22. Agiotis, L.; Theodorakos, I.; Samothrakitis, S.; Papazoglou, S.; Zergioti, I.; Raptis, Y.S. Journal of Magnetism and Magnetic Materials 2016, 401, 956-964.

DOI:10.1016/j.colsurfb.2012.10.030

23. Asmathunisha, N.; Kathiresan, K. Colloids and Surfaces B: Biointerfaces 2013, 103, 283-287.

DOI:10.1016/j.nano.2016.01.005

24. Alcantara, D.; Lopez, S.; García-Martin, M.L.; Pozo, D. Nanomedicine: Nanotechnology, Biology and Medicine 2016, 12, 1253-1262. DOI:10.1016/j.taap.2010.08.029

25. Loh, J.W.; Yeoh, G.; Saunders, M.; Lim, L.-Y. Toxicology and Applied Pharmacology 2010, 249, 148-157.

DOI:10.1021/bm0257661

26. Mateo, C.; Torres, R.; Fernández-Lorente, G.; Ortiz, C.;
Fuentes, M.; Hidalgo, A.; López-Gallego, F.; Abian, O.; Palomo, J. M.; Betancor, L.; et al. Biomacromolecules 2003, 4, 772-777. DOI:10.2478/boca-2014-0001

27. Spinelli, D.; Coppi, S.; Basosi, R.; Pogni, R. Biocatalysis 2014, 1, 1-12. DOI:10.2478/boca-2014-0001.

28. National Toxicology Program Epichlorohydrin. Rep Carcinog 2011, 12, 180-183. DOI:10.1016/j.bbapap.2012.03.010

29. Petkova, G.A.; Záruba, K.; Král, V. Biochimica et Biophysica Acta (BBA) - Proteins and Proteomics 2012, 1824, 792-801.

DOI:10.1016/j.ijbiomac.2016.03.031

30. Jiang, X.-P.; Lu, T.-T.; Liu, C.-H.; Ling, X.-M.; Zhuang, M.-Y.; Zhang, J.-X.; Zhang, Y.-W. Int. J. Biol. Macromol. 2016, 88, 9-17. DOI:10.1016/j.jmmm.2008.08.047

31. Lei, L.; Bai, Y.; Li, Y.; Yi, L.; Yang, Y.; Xia, C. Journal of Magnetism and Magnetic Materials 2009, 321, 252-258.

DOI:10.1016/j.bej.2015.04.020

32. Babaki, M.; Yousefi, M.; Habibi, Z.; Brask, J.; Mohammadi, M. Biochemical Engineering Journal 2015, 101, 23-31.

DOI:10.1007/s00449-009-0345-6

33. Bayramoglu, G.; Yilmaz, M.; Yakup Arica, M. Bioprocess Biosyst Eng 2010, 33, 439-448.

DOI:10.1016/j.molcatb.2015.06.004

34. Vasić, K.; Knez, Ž.; Konstantinova, E.A.; Kokorin, A.I.; Gyergyek, S.; Leitgeb, M. Reactive and Functional Polymers 2020, 148, 1-13. DOI:10.1016/j.jbiotec.2006.01.028

35. Kägi, J.H.; Vallee, B.L. J. Biol. Chem. 1960, 235, 3188-3192. DOI:10.1016/j.jmmm.2010.08.008

36. Bradford, M.M. A rapid and sensitive method for the quantitation of microgram quantities of protein utilizing the principle of protein-dye binding. Analytical Biochemistry 1976, 72, 248-254. DOI:10.1016/j.ijbiomac.2014.10.045

37. Bystrzejewska-Piotrowska, G.; Golimowski, J.; Urban, P.L. Waste Management 2009, 29, 2587-2595.

DOI:10.1016/j.btre.2018.e00260

38. Chen, H.; Zhang, Q.; Dang, Y.; Guowei, S. Advanc Journal of Food Science and Technology 2013, 5, 932-935.

DOI:10.1016/j.ijbiomac.2008.01.005

39. Jiang, D.-S.; Long, S.-Y.; Huang, J.; Xiao, H.-Y.; Zhou, J.-Y. Biochemical Engineering Journal 2005, 25, 15-23.

DOI:10.1016/j.procbio.2012.01.012

40. Prousoontorn, M.H.; Pantatan, S. J Incl Phenom Macrocycl Chem 2007, 57, 39-46.

DOI:10.1016/j.reactfunctpolym.2020.104481

41. Talbert, J.N.; Goddard, J.M. Colloids and Surfaces B: Biointerfaces 2012, 93, 8-19. DOI:10.1016/j.colsurfb.2012.01.003.

42. Jamil, N.; Che Man, R.; Suhaimi, S.; Md Shaarani, S.; Iffah Mohd Arshad, Z.; Kholijah Abdul Mudalip, S.; Zubaidah Sulaiman, S. Materials Today: Proceedings 2018, 5, 22036-22042. DOI:10.1016/0003-2697(76)90527-3 


\section{Povzetek}

Mikrobno inhibicijo magnetnih nanodelcev (MNP) prekritih z karboksimetil dekstranom (CMD) smo preučili na dveh bakterijskih kulturah, Escherichia coli in Staphylococcus aureus. Dokazali smo inhibicijske lastnosti CMD-MNP-jev, medtem ko neprekriti MNP-ji niso imeli te lastnosti. Na CMD-MNP smo imobilizirali alkohol dehidrogenazo (ADH) iz Saccharomyces cerevisiae. Poleg tega smo CMD-MNP-je funkcionalizirali z zamreževalcem epiklorhidrinom (EClH) kot alternativa za ADH imobilizacijo. Primerjali smo aktivnost ADH imobilizirane na epoksi funkcionalizirane CMD-MNPje in nefunkcionalizirane. Pod optimalnimi pogoji priprave $\left(4 \%(\mathrm{v} / \mathrm{v}) \mathrm{EClH}, 4^{\circ} \mathrm{C}\right.$ in $\left.0.02 \mathrm{mg} / \mathrm{mL} \mathrm{ADH}\right)$ je imobilizirana ADH ohranila 90\% aktivnosti. Tako imobilizirano ADH smo okarakterizirali z FT-IR, SEM in DLS. 